\title{
W Galicji i nad Socą. Polacy i Słoweńcy na frontach I wojny światowej. V Galiciji in na Soči, Poljaki in Slovenci na frontah I. svetovne vojne, edited by Antoni Cetnarowicz, Dušan Nećak, Stanisław Pijaj, Bojana Jodorović, Historia Jagellonica, Kraków 2016
}

\begin{abstract}
This is a book review of a Polish-Slovene collection of articles, written by Polish and Slovene historians and covering various topics of WWI and how it affected the Polish and the Slovene population of Habsburg monarchy. The articles cover topics such as the political circumstances for Poles and Slovenes in the decades leading up to WWI, the Polish-Slovene relationships, different aspects of WWI, especially the events on the frontlines of Galicia and the Isonzo river, as well as the afterlife of WWI: the construction of war cemeteries and graves for the fallen soldiers.
\end{abstract}

Key words: World War I, war experience, political circumstances within Habsburg monarchy before WWI, warfare, commemoration, Galicia, Isonzo front.

Słowa klucze: I wojna światowa, doświadczenie wojenne, sytuacja polityczna w monarchii habsburskiej przed I wojną światową, wojny, upamiętnienie, Galicja, front Isonzo.

This Polish-Slovene collection of articles is the result of an international, or more specifically, bilateral conference of Polish and Slovene historians held in Cracow in May 2014, and organized by the History Department of the University of Cracow and the Slovene embassy in Warsaw. Before discussing the conference papers presented in that volume in detail, I would like to point out that the idea of this enterprise and its objective seem highly desirable and intriguing, specifically the presentation of Polish and Slovene history of WWI and how they are contrasted. The year 2014, which commemorated the $100^{\text {th }}$ anniversary of WWI, gave impetus to a plethora of new research, new publications and new interest within the research community and the wider public regarding topics related to WWI. Meanwhile, not all of these publications and endeavors were really innovative; I believe this conference and the objective of the resulting papers represent an 
original approach - namely the way in which the experiences of two Slavic people and two national historiographical traditions are contrasted with each other, because historians' points of view and their different interpretations of the past is still very often fenced in by personal national historiography and horizons. Meanwhile, until recently, "Slovene" history of WWI has mainly focused on the Isonzo Front, while "Polish" history of WWI contrarily emphasized on the events at the Galician front, even though a large number of Slovene soldiers fought and died in Galicia, whereas the same is true for Polish soldiers at the Isonzo River. Therefore, we should applaud every incentive to overcome these nationally divided histories and focuses, and try to find more comparative and overarching approaches by also looking at what has been considered until now merely a sideshow to one's own national historiography.

This volume attempts to compare and contrast the experience of the Slovenes and the Poles under Habsburg reign and during WWI. On the one hand, they shared some similar experiences, with the most obvious among them being that parts of their home territories became frontlines and battle fields. On the other hand, within the Habsburg Monarchy they faced very different historical circumstances, conditions and challenges. The first three papers, among the most substantial in this volume, do not tackle WWI, but are dedicated to these differing situations of Poles and Slovenes under Habsburg rule in the $19^{\text {th }}$ century and their mutual opinions of each other. Antoni Cetnarowicz, Rok Stergar, and Zdzisław Darasz stringently point out the different points of departure and the different circumstances of Polish and Slovene politics. Both sides found themselves regularly having very ambivalent feelings about each other, always due to specific political stands and events during the late $19^{\text {th }}$ century (e.g. the Galician resolution, federalism, the Great Eastern crisis, the relationship towards Russia, Pan-Slavic ideas, the "Ukrainian problem" etc.). Moreover, the cultural, literary and political relationship had always been asymmetrical; meaning the Slovene interest in Polish matters had been greater than the interest of the Polish public for the Slovene, which was smaller and rather theoretical in terms of a somewhat abstract slavophile idea of belonging to one large family of Slavic people.

As Cetnarowicz points out, from the Slovene's perspective, the situation of the Ruthenians (whom we would refer to today as Ukrainians), who found themselves on the lower end of Galician politics and opposed by the more dominant Polish higher class, was one of the most overshadowing factors in this relationship, because the Slovenes sympathized with and related to the other "non-historic," small, agrarian Slavic national movement, meaning the Ruthenians. But when it came to other matters, like federalist coalitions in the Austrian parliament (Reichsrat), they found themselves very often on the same side, especially in the late 1860 s when, as Rok Stergar points out, dualism was perceived as only the first step towards a new federalist reorganization of the monarchy. Within this climate, Slovene politicians actively supported the Polish federalist demands in hope that the Poles would support the Slovene demands as well once these were granted - a hope that was soon to be dashed, which creating very negative opinions in the Slovene press about the "egotistic" Poles. By depicting the different coalitions and ideological clashes of Slovene and Polish politicians during the late $19^{\text {th }}$ century, both authors eloquently illustrate how the political circumstances in different parts of the monarchy were deeply connected to each other and that the ambivalent feelings of the Slovene 
intelligentsia towards Polish politics often tell us more about their own positions and struggles than about Polish politics itself.

The article by Zdzisław Darasz, on the other hand, concentrates on the Polish perception of the Slovenes through the lenses of the press, and in particular in the "Świat Słowiański" (1905-1914), the newspaper of the Slavic Club in Krakow, which was engaged in organizing a Slavic ideological movement as an alternative to the Great Russian Pan-Slavism. Unsurprisingly, this movement had a highly Austro-Slavic and Catholic profile and ties to the Slovene "clerical" party, and therefore reported positively about the Slovenes. In this paper we also learn about particular agents, in this case the close ties of "Świat Słowiański" editor Feliks Koneczny and the Slovene priest and political journalist Leopold Lenard, who were individuals that fostered Polish-Slovene relations and thereby a very Catholic Austro-Slavism.

The next four articles tackle WWI, but Slovene contributions prevail in terms of length and quality, so the reader learns a great deal more about Slovenes during WWI than about the Poles. Božo Repe starts with an overview of the events at the Galician frontline, where the majority of Slovene soldiers were stationed and ultimately also wounded or killed, and of the importance of that war experience for the political developments that followed. Due to the considerable number of prisoners of war who learned about Bolshevik ideas during their imprisonment in Russia, the influx of the surviving POWs after 1917 was also an influential factor. Moreover, he briefly discusses the Great powers' reflections on the Slovenes, for whom they showed no interest whatsoever, apart from the strategic region they inhabited. Petra Svoljšak's article then adds to this general storyline the bottom-up perspective of common Slovene soldiers at the Eastern front by making use of ego-documents like diaries, letters, and postcards, thereby depicting the massive horrors and quick disillusionments for which "Galicia" became the ultimate metaphor. In those ego-documents, the Slovene soldiers not only reflected on the events on the battlefield, but also on the scarce, largely unknown and foreign Galician landscape, nature and inhabitants, for whose terrible situation they expressed their heartfelt sympathies. Dušan Nećak then sheds light on the fast rise and the staggering fall of the highest ranking Slav in the Habsburg military, Svetozar Boroević. In 1918 he was awarded the highest officer rank of Field Marshal and praised as one of the greatest war heroes for preventing the Russian Army from crossing the Carpathians in 1915, and for serving as the commanding officer of the $5^{\text {th }}$ Army in the battles at the Isonzo Front between 1915-17. After the collapse of the Empire, he formally became a citizen of the newly founded State of the Serbs, Croatians and Slovenes, which then robbed him of all honors and decorations. He died impoverished and disillusioned in Klagenfurt in 1920.

The next two articles unfortunately do not live up to their promising titles. Darja Kerec attempts to comment on the Polish-Slovenian relationship during WWI by looking at regional newspapers, all of which were edited by the priest Jožef Klekl from Prekmurje, where journalism was particularly Catholic by nature. Unsurprisingly, they featured similar reports from the battle fields as did all other newspapers, which emphasized stories of Slovene soldiers, who survived by means of their deep Catholic faith. The Poles are mentioned usually only in regard to their Catholic beliefs, whereas the Russian enemy was depicted as the evil counterpart worshipping the wrong faith. The article gives an overview of the beliefs of Klekl as expressed in these newspapers 
from Prekmurje, but does not really deliver on the promise in the title to comment substantially on the Polish-Slovenian relationship during WWI. The next article by Wacław Szczepanik attempts to give an overview of the war experience of military units recruited in Galicia that fought at the Isonzo Front, and in particular the $57^{\text {th }}$ Infantry regiment of Tarnów. Unfortunately, it is little more than an enumeration of battles, maneuvers and troop displacements through the individual battles along the Isonzo River without any further analytical depth.

The last two articles by Kamil Ruszała offer an appealing conclusion to this volume by discussing the horrible costs, effects, and the, so to speak, afterlife of WWI: namely the graves of fallen soldiers, which were placed during WWI and the war cemeteries constructed in the immediate aftermath. In the first article Ruszała reflects on the graves of fallen Galicians at the Isonzo Front, and in the second one on the buried Slovene soldiers on the Galician war cemeteries. While doing so, the author focuses on the activity of the Department for War Graves, which was established as a subunit to the Ministry of War in Vienna in 1915. Their main responsibility was on keeping records and detailed maps of all the burial places. Only after those areas were not part of the actual front line, the department could start to establish more permanent war cemeteries and memorials, which happened earlier in Galicia and in the Isonzo area only during 1918. So in the later years of WWI respectively after, a lot of those initial mass graves were excavated and the bodies buried in more permanent resting places. Moreover, Ruszała manages to shed light on the politics of remembrance and the diverging remembrance interests of the different nations after 1918.

Returning to my initial words of encouragement to stimulate more international and bilateral cooperation among historians, this volume can be called a fine first small step into this direction for the Slovene-Polish relationships. In order to critically reflect on one's own nationally fenced historiography and to shed more light on the shared experience of citizens of different linguistic, cultural and historical backgrounds within the Habsburg Empire - during WWI as well as during other times - further comparative research and international cooperation remains a desirable objective for the future. 